\title{
Curcumin protects against failure to generate a transmembrane potential and protein aggregation of rat liver mitochondria induced by tert- butylhydroperoxides
}

\author{
F.D. Suyatna, S. Susilowati, A. Setiawati
}

\begin{abstract}
Abstrak
Kurkumin, bahan aktif tanaman kurkuma diduga bermanfaat dalam pengobatan penyakit hati. Dalam penelitian terdahulu, diperlihatkan efek protektif kurkumin terhadap peroksidasi lipid dan swelling mitokondria yang diisolasi dari hati tikus karena pemberian $t$-butilhidroperoksida $(t-B u O O H)$. Dalam penelitian ini, pemberian $t$-BuOOH $90 \mu M$ menyebabkan mitokondria tidak dapat membentuk potensial transmembran ( $\Psi m$ ). Kegagalan pembentukan potential transmembran diduga berhubungan dengan transisi permeabilitas dan apoptosis. Dari 3 dosis kurkumin yang dicoba $(0,5 \mu M, 2,5 \mu M$ dan 5,0 $\mu M)$, ternyata kurkumin dosis 2,5 $\mu M$ dapat mencegah kegagalan pembentukan potensial transmembran akibat t-BuOOH $(79,13 \pm 6,28 \%)$. Pemeriksaan elektroforesis protein mitokondria menunjukkan kurkumin $1000 \mu M$ dapat mencegah agregasi protein yang terjadi akibat t-BuOOH. Dari penelitian ini diperlihatkan efek proteksi kurkumin terhadap kerusakan sistem pembentukan energi dan protein mitokondria yang disebabkan oleh t-BuOOH. (Med J Indones 2007; 16:139-45)
\end{abstract}

\begin{abstract}
Curcumin, an active ingredient of curcuma plant has been thought to be beneficial in the treatment of liver diseases. In the previous studies, we have shown the protective effects of curcumin against lipid peroxidation and swelling of the rat liver mitochondrial preparation induced by tert-butylhydroperoxide $(t-B u O O H)$. In the present study, the administration of $t-B u O O H$ of $90 \mu M$ caused the mitochondria failed to generate a transmembrane potential ( $\Psi m)$. Of 3 doses of curcumin administered (0.5 $\mu M, 2.5 \mu M$ dan $5.0 \mu M)$ the maximum protective effect against failure to generate a transmembrane potential caused by $t$ - BuOOH was obtained by $2.5 \mu M$ of curcumin $(79.13 \pm 6.28 \%)$. Further, curcumin of $1000 \mu \mathrm{M}$ could prevent protein aggregation formation caused by $t$-BuOOH in the electrophoretogram. This study shows the protective effects of curcumin against damaged of energy production system and protein of the mitochondria caused by $\mathrm{t}-\mathrm{BuOOH}$. (Med J Indones 2007; 16:139-45)
\end{abstract}

Keywords: curcumin, $t$-BuOOH, mitochondria, transmembrane potential, protein electrophoresis.

Oxidative stress has been thought to play an important role in the pathogenesis of toxic and infectious liver diseases. Currently, there are no specific medicines that can be used in the treatment of hepatitis. Various efforts have been tried to develop reliable remedies for the diseases. One among those is empirical approach, i.e. to explore the potential use of certain herbs like curcuma rhizomes and their active ingredient, curcumin. In the previous paper, we have described the potent antioxidant activity of curcumin ${ }^{1}$ and its inhibitory effect against mitochondrial swelling induced by t-butylhydroperoxide $(\mathrm{t}-\mathrm{BuOOH}){ }^{2}$

Department of Pharmacology \& Therapeutics, Medical Faculty University of Indonesia, Jakarta, Indonesia
In the present study we demonstrate the protective effect of curcumin against failure of transmembrane potential generation and prevention of protein damage of rat liver mitochondria induced by $\mathrm{t}-\mathrm{BuOOH}$.

\section{METHODS}

\section{Materials}

Curcumin, EGTA, Trizma $\mathrm{HCl}$, bovine serum albumin (BSA), t-BuOOH, rotenone, safranin $\mathrm{O}$ were purchased from Sigma Chemical Co., USA. Sucrose, Folin Ciocalteus phenol reagent, 2-6 dichlorophenol indophenol, glycine, trisaminomethane, sodium dodecyl sulphate were from E. Merck, Darmstadt, Germany. Ammonium 
persulfate, TEMED, acrylamide, bisacrylamide, broad range molecular weight protein standard, Coomassie brilliant blue, dithiothreitol were purchased from Bio Rad Laboratories Inc. USA. Other analytical grade reagents of the highest purity available were purchased from either Sigma Chemical Co. or E. Merck.

\section{Isolation of mitochondria}

The method of isolation of rat liver mitochondria was carried out as described in the previous study ${ }^{3}$ with minor modification. ${ }^{2}$

Mitochondrial transmembrane potential $(\Delta \Psi \mathrm{m})$ were evaluated using safranin 0 as the indicating dye in a Perkin-Elmer UV-visible lambda 3B spectrophotometer. The procedure was conducted essentially as described by Mittnacht et $\mathrm{al}^{4}$, except that the mitochondrial proteins used were $1.2-1.4 \mathrm{mg} / \mathrm{ml}$ and that $\Delta \Psi \mathrm{m}$ was measured by substracting the absorbance obtained at $516 \mathrm{~nm}$ (A 516) with that obtained at 495 nm (A 495).

\section{Gel electrophoresis}

Polyarcrylamide gel electrophoresis was carried out in $10 \%(\mathrm{w} / \mathrm{v})$ resolving gel with a $3 \%(\mathrm{w} / \mathrm{v})$ acrylamide stacking layer as described by Laemmli. ${ }^{5}$

Prior to electrophoresis an amount of 40-60 $\mu \mathrm{g}$ of mitochondrial protein was incubated for $30 \mathrm{~min}$ at $37^{\circ} \mathrm{C}$ in the presence or absence of $\mathrm{t}-\mathrm{BuOOH}$, various concentrations of curcumin or other substances. Thereafter, the samples were dissolved in a solution containing $60 \mathrm{mM}$ Tris $\mathrm{HCl} \mathrm{pH} 6.8,40 \mathrm{mM}$, DTT, $10 \%$ sucrose, $3 \%$ SDS, $0.001 \%$ bromophenol blue and incubated for $30 \mathrm{~min}$ at $37^{\circ} \mathrm{C}$. The samples were applied onto the gel in a vertical mini Protean II Electrophoresis Cell (Bio Rad) system and stained with Coomassie brilliant blue.

\section{Statistical analysis}

The degree of normality and variant homogeneity of the data on transmembrane potential were tested by Kolmogorov-Smirnov (K-S test for rankable scores) and $\mathrm{F}$ test ${ }^{16}$, respectively. Since the data obtained showed a normal and homogeneous distribution, they were analyzed using the related one-way ANOVA followed by Tukey method ${ }^{7}$ at a significant level of $\alpha$ $=0.05$.

\section{RESULTS}

\section{Extent of purification of the isolated mitochondrial preparation}

The mitochondrial preparation was homogenously purified as shown by the high relative specific activity (RSA) of succinate dehydrogenase of $35.73 \pm 2.78$; the mitochondrial protein yield was $19.96 \pm 1.95 \mathrm{mg} / \mathrm{g}$ wet liver. ${ }^{2}$

\section{Mitochondrial transmembrane potential ( $\Psi \mathrm{m})$}

The ability of the mitochondria to generate transmembrane potential was influenced by incubation time, incubation temperature and in vitro aging, SET medium, and the protein content of the mitochondrial preparation.

The transmembrane potential was evaluated using safranin $\mathrm{O}^{4}$. Mitochondrial energization caused a decrease in the maximum absorption of $25 \mathrm{mM}$ safranin $\mathrm{O}$ from $516 \mathrm{~nm}$ to $495 \mathrm{~nm}$ after addition of 3 $\mathrm{mM}$ succinate, which was thought to be the result of the dye accumulation. ${ }^{8,9}$ The mitochondria were still able to generate transmembrane potential when the assay was conducted immediately after addition of t-BuOOH. However, the mitochondria failed to generate transmembrane potential when they were incubated with $\mathrm{t}-\mathrm{BuOOH}$ for $60 \mathrm{~min}$ at $37^{\circ} \mathrm{C}$. Since the mitochondrial preparation underwent a rapid in vitro aging when they were left at room temperature, they were kept on ice after isolation and the measurement of the transmembrane potential was carried out at room temperature. Suspending the mitochondria in SET-34 medium did not result in the generation of transmembrane potential in control preparation. Dilution of SET-34 with water (25:34) gave an optimal result. Use of $0.25 \mathrm{M}$ sucrose gave similar results, but in vitro aging occurred faster than that after dilution of SET-34 with $\mathrm{H}_{2} \mathrm{O}$. Finally, the results would be optimal when the amount of protein added was $1.2-1.4 \mathrm{mg} / \mathrm{ml}(1.2-1.4 \mathrm{mg} / \mathrm{ml})$. Table 1, Figures 1,2 depict the results of study on mitochondrial transmembrane potential. 
Table 1. Percentage of protection against failure of the mitochondria to generate a membrane potential

\begin{tabular}{c|ccccccccc}
\hline & \multicolumn{8}{|c}{$\%$ of protection } \\
\hline Group & $\mathrm{C}$ & $\mathrm{IC}$ & $\mathrm{IC}_{05}$ & $\mathrm{IC}_{2.5}$ & $\mathrm{IC}_{25}$ & $\mathrm{ID}$ & $\mathrm{ID}_{05}$ & $\mathrm{ID}_{2.5}$ & $\mathrm{ID}_{25}$ \\
\hline Mean $\pm \mathrm{SD}$ & 100 & 92.20 & $89.18^{1}$ & $87.54^{1}$ & $43.35^{1}$ & 0 & $30.97^{2}$ & $79.13^{2}$ & $39.29^{2}$ \\
& & 2.20 & 6.67 & 8.33 & 4.53 & 0 & 2.87 & 6.28 & 3.52 \\
\hline
\end{tabular}

C : control mitochondria

IC : mitochondria incubated without curcumin

IC0.5-25 : mitochondria incubated with curcumin of $0.5,2.5$ and $25 \mu \mathrm{M}$

ID : mitochondria incubated with $90 \mu \mathrm{M}$ t-BuOOH

ID0.5-25 : mitochondria incubated with $90 \mu \mathrm{M} \mathrm{t}-\mathrm{BuOOH}$ and curcumin of $0.5,2.5$ and $25 \mu \mathrm{M}$

$1 \quad$ : significantly different from group $\mathrm{C}(\mathrm{p}<0.05)$

$2 \quad$ : significantly different from group ID $(\mathrm{p}<0.05)$
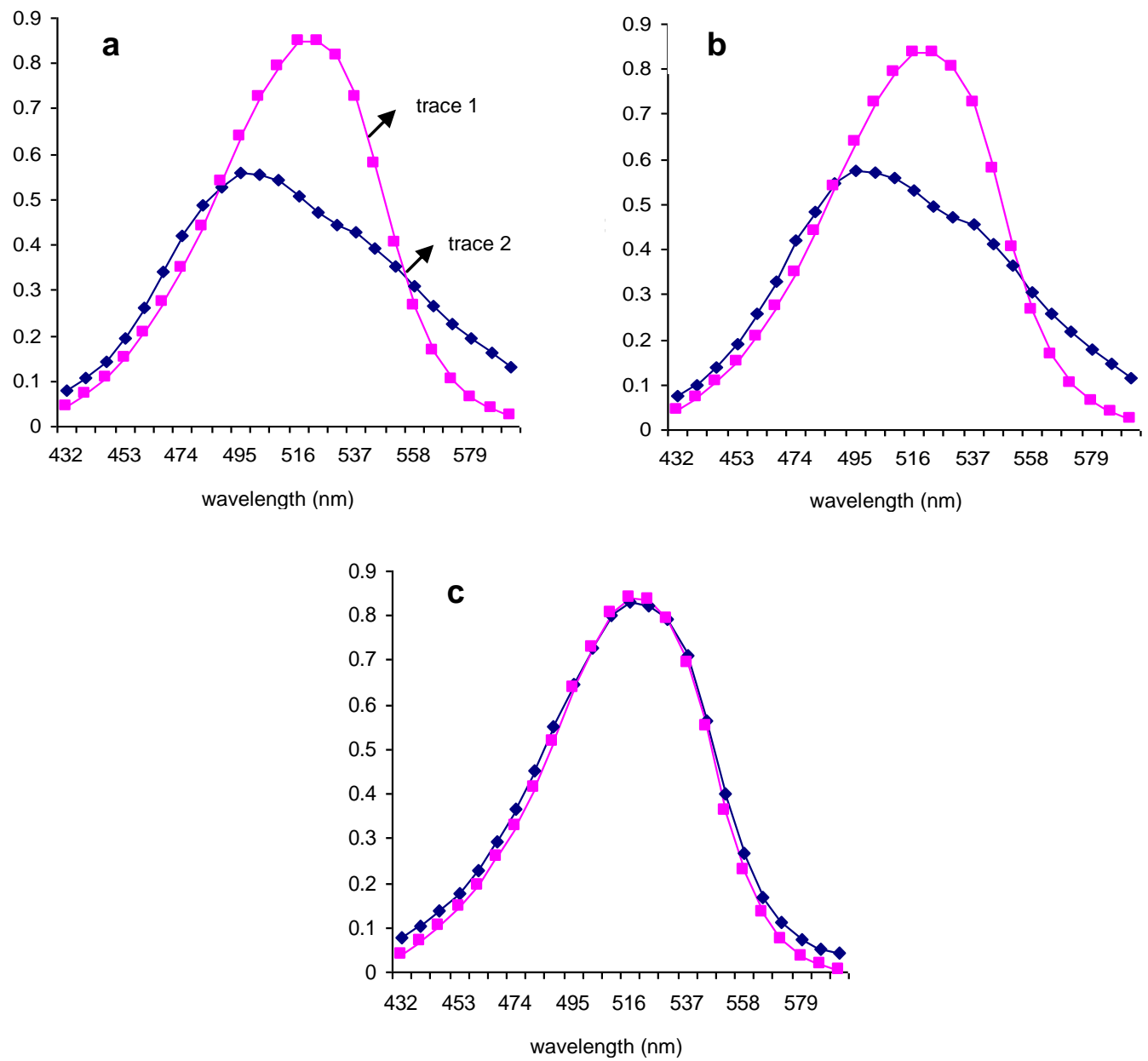

Figure 1. Inability of mitochondria to generate a membrane potential upon addition of $t$-BuOOH.

a. Control mitochondria incubated with $2.5 \mu M$ safranin $O$ before (tracing 1) and after (tracing 2) addition of $3 \mu M$ succinate. The maximum absorption of safranin $O$ was decreased from $516 \mathrm{~nm}$ (tracing 1) to $495 \mathrm{~nm}$ (tracing 2), showing mitochondrial energization and the ability to generate membrane potential

b. Mitochondria incubated with curcumin of $2.5 \mu \mathrm{M}$ in the absence of $t-B u O O H$, showing the ability to generate membrane potential.

C. Mitochondria incubated with $90 \mu \mathrm{M}$ t-BuOOH failed to generate a membrane potential. 

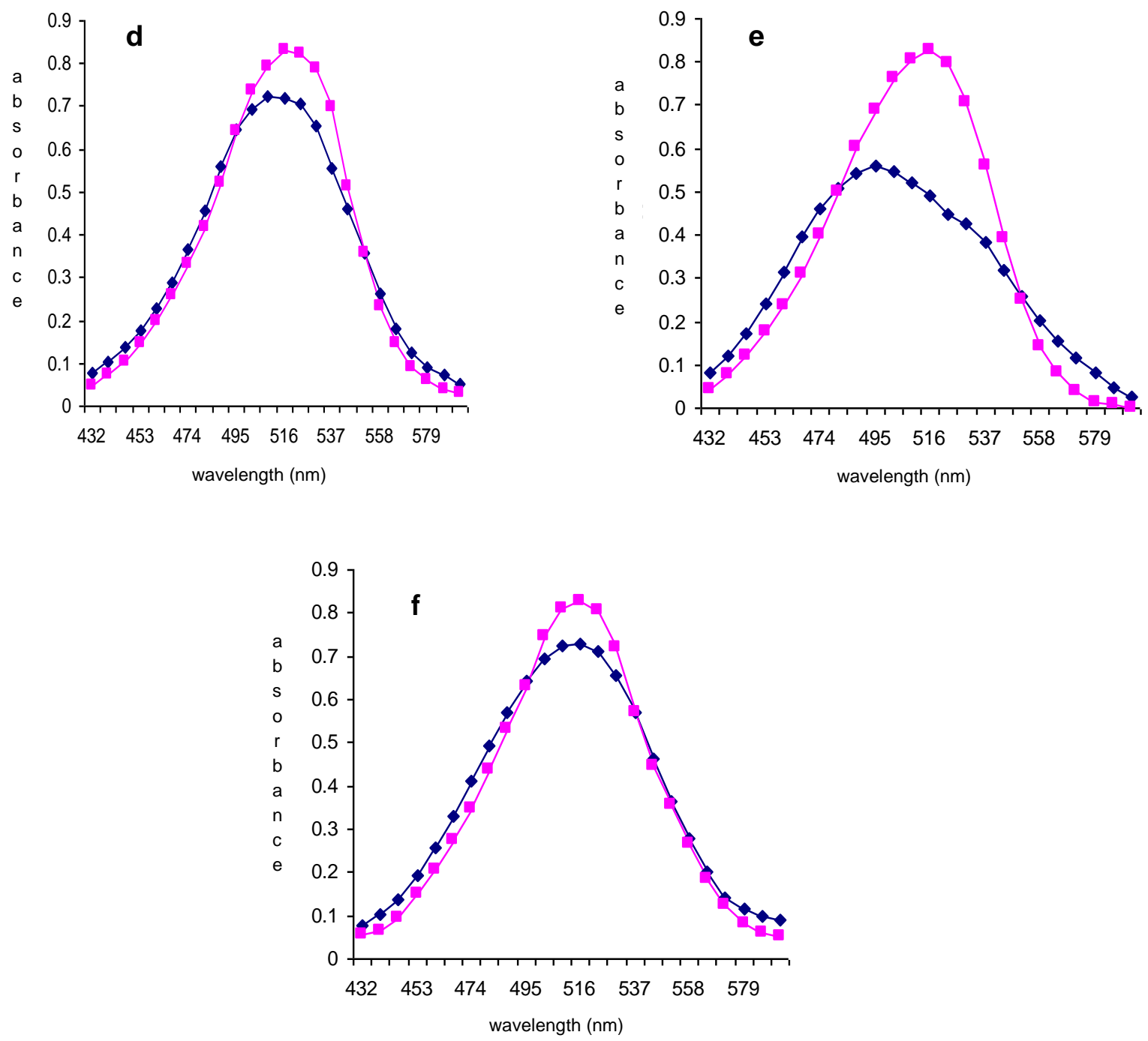

Figure 2. The effects of curcumin of $0.5 \mu M(d), 2.5 \mu M(e)$ and $5.0 \mu M(f)$ against failure to generate membrane potential induced by $90 \mu \mathrm{M}$ - $\mathrm{BuOOH}$.

The maximum protective effect was obtained after preincubation with curcumin of $2.5 \mu M(e)$.

Incubation of mitochondria without curcumin (IC) with curcumin of low dose $\left(\mathrm{IC}_{0.25}\right)$ and intermediate dose $\left(\mathrm{IC}_{2.5}\right)$ in the absence of $\mathrm{t}-\mathrm{BuOOH}$ did not differ among each other, but differed from control (C) in the ability to generate transmembrane potential. At high dose $\left(\mathrm{IC}_{25}\right)$, curcumin even caused a significantly less ability of the mitochondria to generate transmembrane potential in comparison with that of the IC group.

Incubation of mitochondria with $90 \mu \mathrm{M}$ t-BuOOH resulted in a complete inability to generate transmembrane potential (ID). Curcumin of $2.5 \mu \mathrm{M}\left(\mathrm{IC}_{25}\right)$ showed the highest protection against failure to generate tranmembrane potential $(79.13 \pm 6.28 \%)$, whereas at lower $(0.25 \mu \mathrm{M})$ and higher doses $(25 \mu \mathrm{M})$, repectively, the protective effects were much lower $(30.97 \pm 2.87 \%$ and $39.29 \pm 3.52 \%)$

\section{Polyacrylamide gel electrophoresis (PAGE)}

The alteration of polypeptide pattern of mitochondrial preparation caused by t-BuOOH and the protective effects of various doses of curcumin were studied using gel electrophoresis. 
When the mitochondrial preparation was incubated with $90 \mu \mathrm{M}$ of $\mathrm{t}-\mathrm{BuOOH}$ for $30 \mathrm{~min}$ at $37^{\circ} \mathrm{C}$ and run on PAGE, the electrophoretogram showed protein aggregates at the origin and a decreasing intensity of the protein band of $116 \mathrm{kD}$ (Fig. 3). The alteration of the mitochondrial polypeptide pattern induced by $\mathrm{t}$ $\mathrm{BuOOH}$ could be restored to normal by curcumin of $1000 \mu \mathrm{M}$ added just prior to $\mathrm{t}-\mathrm{BuOOH}$. Curcumin of less than $1000 \mu \mathrm{M}$ and more than $2000 \mu \mathrm{M}$ did not give protective effect.

DTT of $0.15 \mathrm{mM}, 0.45 \mathrm{mM}$ and $1.35 \mathrm{mM}$ were also protective against the mitochondrial polypeptide pattern alteration, whereas DMSO of 3\% (v/v) was not.

\section{DISCUSSION}

Our previous results showed that t-BuOOH of $90 \mu \mathrm{M}$ caused swelling of the mitochondria isolated from rat liver and that curcumin of $2.50 \mu \mathrm{M}$ was protective against the swelling. ${ }^{2}$ Swelling proceeded after mitochondrial permeability transition pore (MPTP) opening and might be an initial signal in the cascade process leading to cell death. ${ }^{10}$

The protective effect of curcumin against mitochondrial membrane alteration induced by $\mathrm{t}-\mathrm{BuOOH}$ was shown by the present study on mitochondrial transmembrane potential $(\Psi \mathrm{m})$.

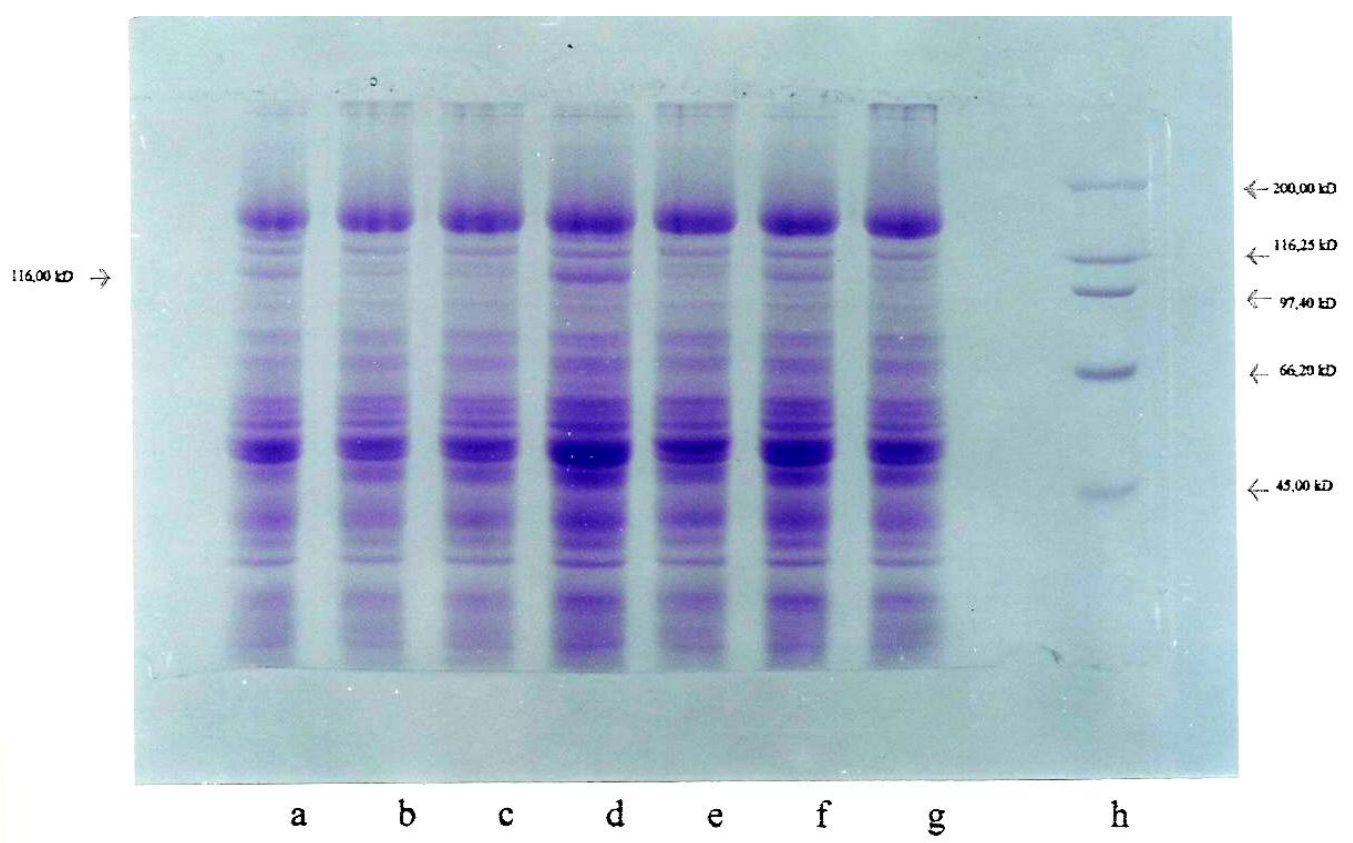

Figure 3. SDS-PAGE electrophoresis of mitochondrial proteins.

Lanes a: control; $b: t$-BuOOH-treated mitochondria; $c$-g: $t$-BuOOH-treated mitochondria in the presence of curcumin of $0.5 \mu M$ (c), $2.5 \mu M(d), 250 \mu M(e), 500 \mu M$ dithiothreitol (f) and 10\% dimethylsulfoxide $(\mathrm{g})$. Lane $h$ : low molecular weight standard.

There was a decrease in the intensity of a polypeptide band of $116 \mathrm{kD}$ in the t-BuOOH-treated mitochondria (b), but restored to control upon incubation with curcumin of $2.5 \mu M(d)$ and dithiothreitol of $500 \mu M(f)$.

The amount of mitochondrial protein run on a $10 \%$

SDS-PAGE was $60 \mathrm{mg}$. 
In this study, the optimal concentration of curcumin that provide optimal protection was $2.5 \mu \mathrm{M}$, which was similar to that obtained in the swelling experiment. Tert butylhydroperoxide, a generator of hydroxyl radicals appeared to trigger the formation of MPTP, by peroxidation of lipid or protein cross linking of the mitochondrial membrane. Current opinion proposed the association of failure of transmembrane potential generation with permeability transition. According to Susin et $\mathrm{al}^{11}$, the formation of MPTP which allowed diffusion of ions and small molecules of less than 1500 daltons eventually resulted in collapse of transmembrane potential. The ability of curcumin of $2.5 \mu \mathrm{M}$ to prevent the failure of transmembrane potential generation supports this opinion. The mechanism by which curcumin protects against swelling and failure to generate the transmembrane potential induced by $\mathrm{t}-\mathrm{BuOOH}$ has not been clearly elucidated. Curcumin was thought to conjugate with GSH leading to some reduction of GSH level ${ }^{12}$ or it may be metabolized by peroxidases to prooxidant phenoxyl radicals which could oxidize GSH or NADH. ${ }^{13}$ Although it may have some reduction of GSH level, curcumin could still be preventive against $\mathrm{t}-\mathrm{BuOOH}$ induced oxidation of mitochondrial membrane. ${ }^{1}$ It might be possible that curcumin spares the GSH content to certain extent by scavenging the hydroxyl radicals generated by t-BuOOH. Tert-butylhydroperoxide in the presence of $\mathrm{Fe}^{2+}$, produces hydroxyl radicals by the reaction:<smiles></smiles>

Curcumin incorporated in the membrane behaves as a chelating agent for $\mathrm{Fe}^{2+}$ ion thereby inhibits the formation of hydroxyl radical

Curcumin may also act as a free radical scavenger by means of its phenolic and methoxy group ${ }^{14,15}$ and that biophysical calculation concluded that the $\mathrm{OH}$ bond is the most important region of curcumin as antioxidant. ${ }^{16}$

The generation of hydroxyl radical by t-BuOOH caused damage of mitochondrial proteins as shown by the formation of protein aggregates and the reducing intensity of a polypeptide band of $116 \mathrm{kD}$ after electrophoresis. Tert-butylhydroperoxide rendered protein cross-linking by the reactions:

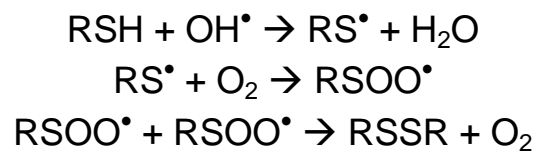

Protein aggregation formation of high molecular weight due to protein thiol oxidation was also obtained when mitochondrial membranes were incubated with $\mathrm{Ca}^{2+}$ and diamide ${ }^{17}$ or peroxynitrite. ${ }^{18}$ Some of the reduced polypeptide band of $116 \mathrm{kD}$ appeared to be a constituent of the aggregates, since their visibility were inversely correlated.

Structural damage of mitochondrial membrane protein might lead to membrane permeabilization that eventually results in $\Psi \mathrm{m}$ collapse and swelling. Curcumin and DTT as shown by our electrophoresis study prevented loss of a polypeptide band of $116 \mathrm{kD}$. For the same amount of protein incubated, curcumin could inhibit swelling with a similar optimal concentration as that used in the study of mitochondrial transmembrane potential in the presence of $\mathrm{t}-\mathrm{BuOOH}$.

The stoichiometry of curcumin (mg) vs. t-BuOOH (molarity) in both conditions was 1:4. The amount of curcumin needed to prevent protein cross-linking in the electrophoresis study, however, was much higher (12:1), making it difficult to reconcile with the data obtained from the swelling and transmembrane potential studies.

It might be entirely possible that the affected polypeptide band of $116 \mathrm{kD}$ was not of mitochondrial membrane origin, since at the same concentration of $\mathrm{t}-\mathrm{BuOOH}$ and amount of protein added, swelling and failure to generate transmembrane potential could be significantly prevented by a much lower concentration of curcumin. Based on the above consideration, we believed that the protein aggregates and the reduced intensity of polypeptide band of $116 \mathrm{kD}$ did not reflect subtle changes of mitochondrial membrane proteins. These results suggest that in order to reduce structural damage of mitochondrial proteins caused by t-BuOOH, a higher concentration of curcumin is needed.

The present study showed that curcumin could prevent failure to generate transmembrane potential and structural protein damage of rat mitochondria caused by t-BuOOH.

\section{Acknowledgement}

This study was partially supported by the URGE Project Batch III. 


\section{REFERENCES}

1. Suyatna FD, Djohan R, Nafrialdi, Suherman SK. The antioxidant effects of curcumin on rat liver mitochondrial dysfunction induced by tert-butylhydroperoxide. J Ecophysiol Occup Health. 2004; 4: 145-51.

2. Susilowati S, Suyatna FD, Setiawati A. The prevention of curcumin against rat liver mitochondrial swelling induced by tert-butylhydroperoxide. Med J Indon. 2006; 15: 131-6.

3. Towers NR, Dixon H, Kellerman GM, Linnane AW. Biogenesis of mitochondria. The sensitivity of rat liver mitochondria to antibiotics; a phylogenetics difference between a mammalian system and yeast. Ann Biochem Biophys. 1972; 151: 361-9.

4. Mittnacht S. Jr, Farber JL. Reversal of ischemic mitochondrial dysfunction. J Biol Chem 1981; 256: 1199-206.

5. Laemmli UK: Cleavage of structural protein during the assembly of the head of bacteriophage T4. Nature. 1970; 227: 680-5.

6. Meddis R. Statistical handbook for non-statistians. Mc Graw-Hill. 1975: 65: 124.

7. Elzey FF. Introductory statistics: a microcomputer approach. Brooks/Cole, 1985; 153: 168-269.

8. Akerman KE, Jarvisalo JO. Effects of ionophores and metabolic inhibitors on the mitochondrial membrane potential within isolated hepatocytes as measured with safranin method. Biochem J. 1980; 192: 183-90.

9. Colonna R, Massari S, Azzone GF, Ziche B, Veronese P. The problem of cation-binding sites in the energized membrane of intact mitochondria. Eur J Biochem. 1973; 31: 577-85.

10. Bernardi P, Scorrano L, Colonna R, Petronilli V, Di Lisa F. Mitochondria and cell death. Eur J Biochem. 1999; 264: 687-701.
11. Susin SA, Zamzami N, Kroemer OT. The cell biology of apoptosis: evidence for the implication of mitochodnria. Apoptosis. 1996; I: 231-42.

12. Donatus IA, Vermeulen NPE. Cytotoxic and cytoprotective activities of curcumin. Effect on paracetamol-induced cytotoxicity lipid peroxidation and glutathione depletion in rat hepatocytes. Biochem Pharmacol. 1990; 39: 1869-75.

13. Galati G, Sabzevari O, Wilson JX, O'Brien PJ. Prooxidant activity and cellular effects of the phenoxyl radicals of dietary flavonoids and other polyphenolics. Toxicology. 2002; 177: 91-104.

14. Patro BS, Rele S, Chintalwar GJ, Chattopadhyay S, Adhikari S, Mukherjee T. Protective activities of some phenolic 1.3-diketones against lipid peroxidation. Possible involvement of the 1.3-diketones moiety. ChemBiochem. 2002; 3: 364-70.

15. Wei Q-Y, Chen W-F, Bo A, Li Y, Liu ZL. Inhibition of lipid peroxidation and protein oxidation in rat liver mitochondria by curcumin and its analoques. Biochim Biophys Acta. 2006;1760:70-7.

16. Wright JS, Predicting the antioxidant activity of curcumin and curcuminoids. J Mol Struct. (Theochem) 2002; 591: 207-17.

17. Fagian MM, Silva LP, Martins LS, Vercesi AE. Membrane protein thiol cross-linking associated with the permeabilization of inner mitochondrial membrane by Ca2+ plus peroxidants. J Biol Chem. 1990;265: 19955-60.

18. Galdeha FR, Thomson L, Fagian MM, Costa ADT, Radi R, Vercesi AE. Independent permeabilization of inner mitochondrial membrane by peroxynitrate is mediated by membrane protein thiol cross-linking and lipid peroxidation. Arch Biochem Biophys. 1997; 342(2): 243-50. 